http://jmscr.igmpublication.org/home/ ISSN (e)-2347-176x ISSN (p) 2455-0450

crossref DOI: https://dx.doi.org/10.18535/jmscr/v7i10.74

Journal Of Medical Science And Clinical Research

\title{
Estimation of Vitamin D Level in Women Attending in Tertiary Care Hospital at Muzaffarpur, Bihar
}

\author{
Authors \\ Dr Anant Prasad ${ }^{1}$, Dr Anita Suneel ${ }^{2 *}$ \\ ${ }^{1}$ Associate Professor and H.O.D., Department of Biochemistry, S. K. Medical College, Muzaffarpur \\ ${ }^{2}$ Associate Professor, Department of Biochemistry, S. K. Medical College, Muzaffarpur \\ *Corresponding Author \\ Dr Anita Suneel \\ Associate Professor, Department of Biochemistry, S. K. Medical College, Muzaffarpur, India
}

\begin{abstract}
Objective: In recent years lots of interest has been shown in the area of detecting in Vitamin D deficiency in patients suspected of Osteoporosis and Osteomalacia. While the techniques of assay have improved the need and significance of such studies. Raising the treatment cost for patients may not be justified in many cases. The aim of present study was to determine the evaluation of Vitamin D level in the different age group of woman attending in tertiary care hospital and also validity of its results.

Materials and Methods: A total of 96 woman with age group ranges from 21 to 70 years attending in the different OPD and IPD with different bony or non bony complains were included in the study. After thorough clinical history, all the patients were subjected to proper clinical examination and referred to our department for Vitamin D estimation. Quantitative determination of Vitamin D estimation was done by fully automated Architect machine supplied by Roche pharma by CMIA (Chemiluminiscent Microparticle Immunoassay) methods.

Result: Out of the 96 woman 38 (39.58\%) women were belonged to rural areas where as $58(60.42 \%)$ woman from the urban side. Test value showed that Vitamin D level was sufficient in age between 21 to 30 years. Between 31- 40 years of age $25 \%$ woman were found to be deficient level of vitamin $D$ and $33.33 \%$ woman has insufficient level of vitamin D. Age between 41-50 years $60 \%$ woman had deficient level of vitamin D and $20 \%$ were found to be Insufficient level of vitamin D. Age between 51-60 years $76.92 \%$ woman had deficient level of vitamin $D$ and $15.38 \%$ were found to be Insufficient level of vitamin D. Age above 60 years $87.5 \%$ were Deficient level of vitamin D and $3.125 \%$ had Sufficient level of vitamin D. Rural background women with increase parity were found to be highly deficient level of vitamin $D$.

Conclusion: Measurement of Vitamin D status provides opportunities for Preventive and Therapeutic intervention. Serum Vitamin D level Estimation may be of value to select the patient who are suffering from Vitamin D deficiency and starting on empirical therapy of Vitamin D.
\end{abstract}

\section{Introduction}

Vitamin D is a fat soluble steroid prohormone mainly produced photochemically in the skin from
7 dehydro cholecalciferol. Biologically there are two forms of Vitamin D are present, one is Vitamin D3 (Cholecalciferol) and another is 
Vitamin D2 (Ergocalciferol). Both can be absorbed from food, with Vitamin D2 being artificial source only $10-20 \%$ of Vitamin D is converted to the active hormone 1, $25(\mathrm{OH}) 2$ Vitamin D through to hydroxylation reaction. The first hydroxylation converts Vitamin D into 25$\mathrm{OH}$ Vitamin $\mathrm{D}$ in the Liver. The second hydroxylation converts 25-OH Vitamin D into Biologically active 1, $25(\mathrm{OH}) 2$ Vitamin D in Kidney as well as many other cells of the body.

The major storage form of Vitamin D is $25-\mathrm{OH}$ Vitamin D and is present in the blood at up to 1000 fold higher concentration compared to the active 1,25 (OH) Vitamin D. 25- OH Vitamin D has a half like of 2 to 3 weeks versus 4 hours for $1,25(\mathrm{OH}) 2$ Vitamin D. Therefore 25- $\mathrm{OH}$ Vitamin $D$ is estimation of choice for determination of Vitamin D status. Epidemiological studies have shown a high global prevalence of Vitamin D in sufficiency and deficiency.

Vitamin D deficiency is prevalent in India, a finding that is unexpected in a tropical country with abundant sunshine. Risk factors for Vitamin D deficiency include low Sun exposure, malnutrition, malabsorption syndrome, Liver or Kidney Diseases. Vitamin D deficiency is a cause of secondary hyperparathyroidism and disease resulting in impaired bone metabolism like Rickets, Osteoporosis and Osteomalacia.

The measurement of Vitamin D status provides opportunities for preventing and therapeutic intervention. Vitamin D plays important role in both bone absorption and bone deposition, in smaller quantities they promote bone calcification and enhances mineralization of bone.

\section{Materials and Methods}

Present study was a prospective study conducted in the department of Biochemistry, Sri Krishna Medical College, Muzaffarpur, Bihar during the period of April 2019 to September 2019. A total of 96 adult, pre and postmenopausal woman with age group ranges from 21 to 70 years attending in the Gynecological, medical, orthopedic or surgical
OPD and IPD with different bony or non bony complains were included in the study. After thorough clinical history, all the patients were subjected to proper clinical examination and referred to our department for Vitamin D estimation.

The study participants were told about the purpose of the study and also the potential benefits that it may result in so as to help them make informed decision as to the participation in the study. They had also been informed that the participation is completely voluntary. Written informed consent was taken. Data pertaining to the various independent variables such as the sociodemographic factors, literacy levels, and number of visits for treatment and tests was recorded. Details regarding their reproductive attributes such as gravidity, age at first pregnancy and birth interval were also sought. It was also asked whether or not they were taking vitamin D or calcium, iron and folic acid supplement during present study periods.

It was the community based cross-sectional study and participants were randomly selected by using multi stage sampling method. From the entire patient's blood sample were taken. Samples were processed according to standard guidelines. Quantitative determination of Vitamin D estimation was done by fully automated Architect machine supplied by Roche pharma by CMIA (Chemiluminiscent Microparticle Immunoassay) methods.

Vitamin D sufficient level is $30-76 \mathrm{ng} / \mathrm{ml}$, deficient level is < $20 \mathrm{ng} / \mathrm{ml}$, insufficient level 20 - $29 \mathrm{ng} / \mathrm{ml}$ and Vitamin D toxicity are > 100 $\mathrm{ng} / \mathrm{ml}$.

\section{Result}

Out of the 96 woman 38 (39.58\%) women were belonged to rural areas where as $58(60.42 \%)$ woman from the urban side. Test value showed that Vitamin D level was sufficient in age between 21 to 30 years. Between 31- 40 years of age $25 \%$ woman were found to be deficient level of vitamin $\mathrm{D}$ and $33.33 \%$ woman has insufficient level of 
vitamin D. Age between 41-50 years $60 \%$ woman had deficient level of vitamin D and $20 \%$ were found to be Insufficient level of vitamin D. Age between 51-60 years 76.92 \% woman had deficient level of vitamin D and $15.38 \%$ were found to be Insufficient level of vitamin D. Age above 60 years $87.5 \%$ were Deficient level of vitamin D and $3.125 \%$ had Sufficient level of vitamin D. Rural background women were found to be highly deficient level of vitamin $\mathrm{D}$. On the basis of parity the data show that as the number of children increases deficiency of Vitamin D becomes more marked.

Table-1 Shows Residential status of woman included in the study.

\begin{tabular}{|l|c|c|}
\hline $\begin{array}{l}\text { Residential status of woman } \\
\text { included in the study }\end{array}$ & $\begin{array}{c}\text { Total no. of woman } \\
\text { included in the study }\end{array}$ & percentage \\
\hline Rural & 38 & 39.58 \\
\hline Urban & 58 & 60.42 \\
\hline
\end{tabular}

Table-2 Shows Levels of Vitamin D in woman included in the study

\begin{tabular}{|c|c|c|c|c|c|c|c|c|}
\hline \multirow{2}{*}{$\begin{array}{l}\text { Age of } \\
\text { woman } \\
\text { in years }\end{array}$} & \multicolumn{2}{|c|}{$\begin{array}{l}\text { Total no. of woman } \\
\text { included in the study }\end{array}$} & \multicolumn{2}{|c|}{$\begin{array}{c}\text { Deficient Level of } \\
\text { Vitamin D } \\
\end{array}$} & \multicolumn{2}{|c|}{$\begin{array}{c}\text { Insufficient Level } \\
\text { of Vitamin D } \\
\end{array}$} & \multicolumn{2}{|c|}{$\begin{array}{c}\text { Sufficient Level of } \\
\text { Vitamin D } \\
\end{array}$} \\
\hline & No. & percentage & No. & percentage & No. & percentage & No. & percentage \\
\hline $21-30$ & 6 & 6.25 & 0 & 0 & 1 & 16.66 & 5 & 83.34 \\
\hline $31-40$ & 12 & 12.5 & 3 & 25 & 4 & 33.33 & 5 & 41.66 \\
\hline $41-50$ & 20 & 20.83 & 12 & 60 & 4 & 20 & 4 & 20 \\
\hline $51-60$ & 26 & 27.08 & 20 & 76.92 & 4 & 15.38 & 2 & 7.69 \\
\hline $61-70$ & 32 & 33.34 & 28 & 87.5 & 3 & 9.37 & 1 & 3.125 \\
\hline Total & 96 & 100 & 63 & $\begin{array}{l}63 / 96 \\
=65 \%\end{array}$ & 16 & $\begin{aligned} & 16 / 96 \\
= & 16.66 \%\end{aligned}$ & 17 & $\begin{aligned} & 17 / 96 \\
= & 17.70 \%\end{aligned}$ \\
\hline
\end{tabular}

\section{Discussion}

In this study we found that women from all age group, Socioeconomic classes irrespective of parity, rural and urban background and educational level had either deficient or insufficient Vitamin D level. So be must provide therapeutic and preventive measures in all these women. Vitamin D supplementation is simple and cost effective with a low likelihood of Toxicity.

We recommend increase supplementation and exposure to sunlight in all women. Better nutritious diet, therapeutic dose of Vitamin D along with calcium supplement must be given to the patient. Therapeutic dose varies from 1000 5000 IU daily for 6 - 8 weeks followed by 200 $400 \mathrm{IU}$ daily with calcium supplement 15 - $20 \mathrm{gm} /$ day of elemental calcium must be given to patient. Severe Vitamin D deficiency can be treated with Pharmacologic repletion initially by $50000 \mathrm{IU} /$ week followed by maintenance therapy $800 \mathrm{IU} /$ day.

\section{Reference}

1. Kennel - KA, Drake MT, Harley DL Vitamin D deficiency in adults, when to test \& how to treat. Mayo clinic proc 2010 August (85/8) 752 - 758.

2. Hollic MF - Vitamin D deficiency N. eng I Med. 357(3) 206/2007.

3. Thacher TD, Charka BL, Vitamin D insufficiency Mayoclin Proc, 2011. January 86 (I) 50'60.

4. Zeils V. Weber, K. Suegiante DW, walf E, Bally R, Erbon RG, Impaired Insulin secreting capacity in mice, lacking a function of Vitamin D receptor.

5. Holick MF - Vitamin D importance in the prevention of cancer, Type I diabetes, heart disease and osteoporosis. AM. J. Clin Nutri, 2004, 79(3), 362 - 371.

6. Deluca HF, overview of general physiologic features and function of Vitamin D, AMI din. Nutri 80:16895, 2004. 
7. Bischaff, Ferriari HA, Dawson - Hughes, B willet $\mathrm{W}$ stachilin $\mathrm{H}$, Bazemore $\mathrm{M}$ Zee R, wong J (2004) fall prevention by Vitamin D treatement. A meta analysis of randomized controlled trials, $\mathrm{J}$ armed. Assoc 291: 1991 - 2006. 